IZA DP No. 5527

Exit Exams and High School Dropout

Dave E. Marcotte

February 2011 


\title{
Exit Exams and High School Dropout
}

\author{
Dave E. Marcotte \\ University of Maryland, Baltimore County \\ and IZA
}

\section{Discussion Paper No. 5527 \\ February 2011}

\author{
IZA \\ P.O. Box 7240 \\ 53072 Bonn \\ Germany \\ Phone: +49-228-3894-0 \\ Fax: +49-228-3894-180 \\ E-mail: iza@iza.org
}

Any opinions expressed here are those of the author(s) and not those of IZA. Research published in this series may include views on policy, but the institute itself takes no institutional policy positions.

The Institute for the Study of Labor (IZA) in Bonn is a local and virtual international research center and a place of communication between science, politics and business. IZA is an independent nonprofit organization supported by Deutsche Post Foundation. The center is associated with the University of Bonn and offers a stimulating research environment through its international network, workshops and conferences, data service, project support, research visits and doctoral program. IZA engages in (i) original and internationally competitive research in all fields of labor economics, (ii) development of policy concepts, and (iii) dissemination of research results and concepts to the interested public.

IZA Discussion Papers often represent preliminary work and are circulated to encourage discussion. Citation of such a paper should account for its provisional character. A revised version may be available directly from the author. 
IZA Discussion Paper No. 5527

February 2011

\section{ABSTRACT}

\section{Exit Exams and High School Dropout}

In this paper, I consider the impact of the expansion of exams students must pass in order to graduate high school on dropout rates. "Exit exams," as these tests are known, have become more common, and more difficult. These exams are controversial, with opponents claiming they drive marginal students out of school, and proponents arguing they align student interests with those of the school and encourage teachers and administrators to provide effort and resources on the students' behalf. I make use of the fact that when states implement exit exams, they first affect a specific graduating class. So in some states, some students in high school are required to pass these exams, while students in the grade above are not. Using a state-grade panel constructed from the Common Core of Data I find evidence that the recent expansion of exit exams has resulted in a modest increase in high school dropout rates in the aggregate, but a large increase among students in $12^{\text {th }}$ grade, where additional attempts to pass exams are not possible. I also find that a policy often used to limit the impacts of exit exams on high school completion has only limited effect: Dropout rates in states where students can earn a diploma or credential even when unable to pass exit exams, dropout increases in $12^{\text {th }}$ grade at about the same rate as in other states without such alternative pathways. This suggests that at least some of the impact is due to stop-out on the part of students.

JEL Classification: $\quad$ 12, 128

Keywords: high school dropout, exit exams, accountability, attainment

Corresponding author:

Dave E. Marcotte

Department of Public Policy

University of Maryland, Baltimore County

1000 Hilltop Circle

Baltimore, MD 21250

USA

E-mail: marcotte@umbc.edu 
Over the course of the past three decades, many advocates of education reform have sought to extend and enhance the role of accountability. In part this has increased focus on the ability of schools and local and state education authorities to generate and sustain learning gains on the part of their students. To a lesser degree, states have imposed expectations on students, and sanctions for failing to meet them. A key form of student level accountability is the requirement for high school students to pass exit exams in order to receive a diploma.

In the 1970 s, concern that high school diplomas were becoming poor indicators of graduates' abilities led many states to adopt minimum competency tests for high school students (Peterson and West, 2003; Pipho, 1978). These tests lived up to their names, and were universally aligned to competency levels well below high school. Even then, administrators and teachers found ways to limit the chances and consequences of poor performance. For example, schools modified curricula, tutored poor performing students and provided pre-tests to boost performance (Walstad, 1984), and commonly re-tested failing students (Goldman, 1984). In the subsequent decades, high school exit exams have become more challenging, and the consequences for poor performance more substantial.

As the exams have moved beyond testing minimum competency, they have also become more widely used. By 2008, students in 25 states were required to pass an exit exam to receive a diploma, with another planning to do so by 2012 (Center on Education Policy, 2008). Currently, exit exams affect nearly 70 percent of students in public high schools in the U.S. (Center on Education Policy, 2008). 
Proponents have advanced many arguments in favor of consequential tests for high school students. These include providing motivation to students, aligning teacher and student interests, and making goals and expectations transparent (Bishop, 2001). There is also evidence that exit exams lead to efficiencies by encouraging instructional and pacing guidelines across schools that align to tested material (Zabala et al., 2007). But, opponents of exit exams raise the objection that imposing additional requirements will only lead to higher rates of failure and dropout for marginal students (Amrein and Berliner, 2002).

While these exams are widespread and expanding, the evidence on their impacts is not settled; either on the achievement the exams are intended to improve or on rates of dropout they are suspected of affecting. In this paper, I attempt to add to what is known about the impact of high stakes exit exams on high school dropout, the measure of educational attainment most central to policy debates on this topic. That the evidence on the impact of exit exams on dropout is not settled can be attributed to a variety of factors. Much of why the evidence remains unclear is due to the fact that exit exams aligned to the high school level are relatively new. The initial research on this question focused on state dropout rates subsequent to the adoption of exit exams during the 1980s and early 1990s. On balance, this evidence found some evidence (though mixed) of increased dropout rates, especially among student groups otherwise at higher risk of dropout. There has been little work done to assess whether state dropout rates have increased more substantially subsequent to the expansion and adoption of exit exams aligned at the high school level over the past decade. 
More recent evidence has used individual level data on students near the minimum passing score on exit exams in select states to identify the impact of failing an exit exam on high school completion. Evidence from these regression discontinuity (RD) studies generally finds no effect of exit exams on educational attainment. Comparing the findings of these RD studies with the earlier aggregate studies is difficult because of differences in the time periods and treatment margins under study.

In this study I contribute to our developing understanding of the impact of exit exams by updating and extending the analysis of their effects on dropout rates in states that adopt exit exams or make them more rigorous in the recent decade of increased accountability. I focus on aggregate dropout rates because research is scant on how overall dropout rates have been affected by the more demanding exit exams implemented over the past decade. Further, aggregate dropout rates are arguably a more important policy concern than treatment effects at the exam cutoff. The barrier imposed by exit exams affects students far below the cut-off, who now confront an additional challenge to graduation. As a policy matter, the impact of exit exams over the entire range of the ability distribution is relevant.

To advance our understanding of the impact of exit exams on states' graduation rates, I expand the scope of analysis beyond what has previously been studied. In particular, I make use of a complete national panel of all states from the early 1990s to the late 2000s, based on the Common Core of Data (CCD) from the National Center for Education Statistics. This provides the most comprehensive and current assessment of the relationship between exit exams and high school dropout. Just as importantly, using a later panel than has heretofore been available, I am able to focus principally on the advent 
of exit exams aligned to the high school level. As I will discuss below, previous work has focused on exit exams which tested levels of competence often at the elementary or middle school level. As one might expect, research on the effects of these minimum competency tests suggest that they have very little effect on outcomes for most students. The new push for exit exams has included a push to align the exams with high school levels of competence. So, not only are more students required to pass these exams, but the exams are becoming more rigorous, and hence one might expect more substantial impacts.

The paper is structured as follows. I first provide a brief history of high school exit exams in the United States. In doing so, I discuss the mechanisms through which these exams might affect student performance, and review the available evidence linking these exams to dropout. I then discuss the empirical approach and data I employ to estimate these pathways. In the penultimate and final sections of the paper I present and then discuss results.

\section{Background:}

Today's high school exit exams are a legacy of the one of the earliest reforms in what has become the accountability movement. In the early 1970s, critics of American education worried about a decline in the quality of schools in the U.S. Much of this concern was fueled by business interests who complained that the skills possessed by graduates of American high schools were low, and falling. Their concern was that this put American business at a disadvantage in the global economy. ${ }^{1}$ This anxiety led to what has been called the "first wave" of accountability reform in public schools: minimum

\footnotetext{
${ }^{1}$ This concern was central to the 1981 "A Nation at Risk" report.
} 
competency testing (Dee, 2003). In the late 1970s, minimum competency tests were introduced in states across the country, assessing basic skills (Pipho, 1978). These tests were usually criterion-referenced, aligned to elementary or middle school levels (Jacob, 2001), and were more often used to identify low performing students for remediation than to serve as a bar above which all graduates must pass (Dee, 2003).

However, over time these exams have become mandatory for students in many states. Passing these exams is necessary to receive a diploma in 23 states, with three more planning to do so by 2012 (Center for Education Policy, 2008). Currently, exit exams affect nearly 70 percent of students in public high schools in the U.S. (Center on Education Policy, 2008).

Exit exams have been the source of considerable controversy from the outset. A key criticism of has always been that these exams will induce marginal students to drop out of high school, with no good alternative. The concern here is that by raising the cost of earning a high school diploma, one would expect that at the margin some students would decide that the time and effort now necessary to earn the high school degree was not an investment worth making (McDill, 1985). Other criticisms of exit exams include the concern that they result in "teaching to the test" or focus too much attention on the learning of marginal students at the expense of students whose academic performance is better (Airasian, 1987; Amrein and Berliner, 2002).

Proponents, on the other hand, point to a number of potential benefits of exit exams on student learning and attainment. First, exit exams could provide incentives for schools to improve education. Jacob (2001) suggests a number of mechanisms through which these tests could affect achievement, such as higher levels of teacher effort or 
improvements to the curriculum. Jacob (2001) points out that a substantial body of literature in education, known as the "effective schools" literature, identifies a number of characteristics of schools that are most associated with academic success. Typical of effective schools are clearly defined objectives, monitoring of students, and remediation for underperforming students (see Purkey and Smith (1985) for a summary). Exit exams essentially require all affected schools to adopt these characteristics. Further, proponents argue that exit exams can improve learning outcomes and attainment by inducing effort and motivation on the part of students. There is little direct empirical evidence on this. One relevant study is that of Roderick and Engel (2001), who examine the Chicago Public School's policy reform to end social promotion. Roderick and Engel study the response of low-performing $6^{\text {th }}$ to $8^{\text {th }}$ graders subsequent to the new policy which raises the stakes of tests and coursework by linking poor performance to grade retention. Roderick and Engel find that the students report (and teachers confirm) greater effort and attention in class and on assignments subsequent to the new policy. Moreover, the behavioral response occurred generally, not as the result of having failed a high-stakes test.

Evidence on the impact of exit exams on academic achievement is limited, and mixed. That the evidence is mixed is in part a result of the fact that these exams are a moving target. The earliest papers to examine achievement effects were looking almost exclusively at minimum competency tests (i.e. tests aligned at grade school levels). More recently, these exams have included tests aligned to high school levels. More difficult exams are likely to have different effects on achievement. A second reason that the results are mixed is that many of the earlier studies used cross-sectional or otherwise 
limited methods which make it difficult to distinguish the effects of exit exams from effects caused by other state-level changes (Dee and Jacob, 2007).

The early evidence on minimum competency tests found that students in states with these tests had higher levels of achievement (Fredricksen, 1994; and Winfield, 1990). These studies were often limited in their design, relying mainly on cross-sectional variation. The early evidence of effects of exit exams on dropout is similarly suggestive, but inconclusive. Griffin and Heidorn (1996) find no impact of failure on minimum competency tests on dropout for marginal students, though they do find higher rates of dropout for better students. Jacob (2001) similarly reports no overall impact of exit exams on dropout, but some evidence for of higher dropout rates for low ability students. Warren, Jenkins and Kulick (2006), however examine evidence from 1973 to 2000 and report that exit exams do lower graduation rates, on average.

Much of the evidence on exit exams in recent years comes from research that exploits student-level data from individual states and regression-discontinuity designs to identify the effects of failing exit exams on students who score just below minimum passing scores. These studies generally find no impact of failing exit exams on dropout or high school completion. See, for example, Martorell's (2005) study using data from Texas, Ou's (2009) examination of New Jersey, and Reardon et al's (2009) study using data from four large districts in California. One study of this type does find evidence that failure on a state's exit exams reduces the likelihood of graduating for low-income students from urban districts in Massachusetts (Papay et al. (2010)).

Comparing the findings from recent RD studies with earlier work that relied on aggregate dropout rates is difficult both because the RD studies focus on a more recent 
period, and because the aggregate studies estimate effects on all students - not just on those near the minimum passing score on exit exams. The impact of a requirement to pass exit exams likely has quite different effects on students at different parts of the achievement distribution. Students at the top are at very low risk for dropout, and an exit exam would likely have little or no effect on that risk. Drop out risk likely rises as one moves down the achievement distribution, but whether the marginal effect of the additional graduation requirement imposed by an exit exam is constant or decreasing in achievement is an empirical question. Neither RD nor aggregate studies can answer this question, but both can give different answers if the effect of exit exams on dropout is not constant. Estimates from aggregate dropout rates are weighted averages of potentially heterogeneous local average treatment effects. For the purposes of policy evaluation this is the important estimate, though, since any and all change in dropout subsequent to the imposition of exit exams is relevant for assessing full social costs.

Evidence on the aggregate impact of exit exams during the No Child Left Behind period is scant. The evidence most directly related to the current paper is that of Dee and Jacobs (2007). Using the Common Core of Data, they examine the impact of implementation of Minnesota's "Basic Skills Tests," or BSTs. Minnesota implemented a set of exit exams that, despite the name, as aligned at a level well above MCTs. The first graduating class required to pass the BSTs was the class of 2000. Dee and Jacob (2007) report that the BSTs reduced the likelihood of high school completion overall, but the effect is insignificant. They find the effect varies by grade, with no significant effect for $9^{\text {th }}$ graders, reductions in dropout rates for students in $10^{\text {th }}$ and $11^{\text {th }}$ grade, but an increased dropout rate in $12^{\text {th }}$ grade. 
The findings from Dee and Jacob's analysis of the effects of Minnesota's Basic Skills Test on dropout rates are obviously limited by the focus on one, relatively homogeneous state. But their work is similar in spirit and strategy to the analyses I conduct here. Rather than focusing on the introduction of one state's tests on dropout using district level data, I use data for all states and exploit cross-state differences in the introduction of high school exit exams.

\section{Data and Approach:}

In this paper, I seek to identify causal estimates of the impacts of these exams on aggregate dropout rates by examining their impact within states, comparing dropout rates in grades newly confronted with a mandatory exit exam to rates within the same state in grades not required to take an exit exam. Because exit exams are phased in so that students in a specific graduating class are announced to be the first group required to pass the exam as a condition of graduation, as exit exams are implemented students in one grade are faced with a new requirement that does not affect students in the same state in the grade above. By examining changes over time in dropout rates for students in states that implement exit exams, I control for underlying changes in educational systems and economies that might be related to both educational policies and dropout. Further, by comparing changes in dropout rates for grades forced to take exams over and above changes for grades not required to pass the same exam, I limit threats to validity due to unmeasured changes over time in factors that would affect dropout that might be coincident with adoption of exit exams, since such changes would likely affect students in more than one grade. Below, I describe both the data and strategy I use to develop these estimates. 
Data

To examine the impact of exit exams on dropout rates I construct a state-year panel data set built on the Common Core of Data (CCD) from the 1992-93 to 2007-08. The CCD is a database collected and maintained by the U.S. Department of Education's National Center for Education Statistics (NCES). The data collected include information on the number and characteristics of students in all public elementary and secondary schools in the U.S. The CCD includes a number of components, but I make use of the State Aggregate Nonfiscal Data component. ${ }^{2}$

The NCES collects CCD data from state education agencies (SEAs), and works with these agencies to develop common reporting definitions. Working with state SEAs, the NCES developed an "event" dropout definition which is used in the CCD (Stillwell, 2010). The CCD definition counts a student as a dropout if he or she had been enrolled in a particular year, but on October 1 of the next academic year the student had not enrolled, graduated, or met exclusion restrictions of transferring to another school, taking temporary absence due to illness, or death (Stillwell, 2010).

There are various ways to measure dropout. Event measures like the one used here are generally preferred to status measures determined by surveying samples from general populations and inquiring about their enrollment/school completion status (Warren, 2005). Still, the CCD's measure fails to pick up subsequent re-enrollment of students who dropout in one year, only to return in a later year (Warren, 2005). However, because the CCD measure requires schools to substantiate reports of student transfer and withdraw, and it accommodates grade retention, it does not suffer from problems that have plagued studies of high school completion rate using ratios of

\footnotetext{
${ }^{2}$ For more information on the CCD, see http://nces.ed.gov/ccd/index.asp.
} 
graduates to enrollment (Warren, 2005; Dee and Jacob, 2007). For my purposes, another advantage of the CCD data is that it provides measures on grade-specific dropout rates. Since the introduction of exit exams affects some grades in a school, but not others, distinguishing between dropout rates by grade is an important aspect of identifying the impact of these tests.

To the CCD data, I first add state level measures of the presence and grade alignment of exit exams. I obtain these measures principally from data reported by the Center for Education Progress, which conducts regular surveys of all state SEAs on exit exams. I have verified measures reported by CEP by comparing to Dee and Jacobs (2007) and have augmented some missing state/year data by contacting state SEAs directly. From this, I generate two measures of exit exams: a binary indicator of whether a student in grade $g$ in state $s$ in year $t$ was required to pass any exit exam as a condition of graduating; and, a separate indicator of whether a student in grade $g$ in state $s$ in year $t$ was required to pass an exam aligned at the high school level as a condition of graduation. Finally, I add measures of employment and income from the U.S. Bureau of Economic Analysis.

\section{Empirical Model}

Using the state-year panel built around the CCD, I estimate models that exploit within-state differences in the introduction of exit exams and/or changes in the level at which these exams were aligned. I employ a model similar to Dee and Jacobs's (2007) work using district level data in Minnesota. To examine the impact of exit exams on dropout rates, I make use of differences in the grades exposed to these exams within 
states. First, I estimate the impact on dropout rates of exposure to exit exams,

conditioning on state/year economic conditions and on state, grade and year fixed effects:

$$
D_{s g t}=\beta_{1} \vec{X}_{s t}+\beta_{2} \vec{E}_{s g t}+\mu_{g}+\phi_{s}+v_{t}+\varepsilon_{s g t}
$$

Where $D_{s g t}$ measures dropout rates in state $s$, grade $g$, in year $t ; X_{s t}$ is a set of controls for labor market conditions in each state and year; $E_{s g t}$ measures whether students in grade $g$ in state $s$ and year $t$ would be required to pass an exit exam to eventually graduate.

In model 1, the impact of these exams is estimated via changes in exposure to exams for students in a grade and state, net of any general state influences on dropout, as well as any grade-specific factors common across states. These might include general cohort or policy factors. A limitation of this specification is that it could confound any state-specific changes in education or cohort quality over time with the implementation of new exit exams. For example, one threat to identification would arise if a decline in educational outcomes within a state spurred the implementation of an exit exam. Since Model 1 controls only for general state effects, it cannot distinguish changes in a particular state's dropout rates across grades from changes due to the implementation of an exam. So, any decline in education/cohort quality over time that would increase dropout rates for students in lower grades might appear to be policy effects, because exams affect students in lower grades first.

However, because of the way exit exams are instituted or modified, the exposure to exit exams varies by grades within a state in any year. For example, Indiana adopted an exit exam, called the Graduation Qualifying Exam and aligned to high school levels in reading and math, for the class of 2000 . Students in that class knew about the requirement before they entered high school. However, students in the class of 1999 did not have to 
pass the exam. So, beginning in $1997,9^{\text {th }}$ graders in Indiana faced the prospect of a high school aligned exit exam, while students in $10^{\text {th }}$ grade and above did not. The next year (1998), $9^{\text {th }}$ and $10^{\text {th }}$ graders faced the GQE as a condition of graduation, $11^{\text {th }}$ and $12^{\text {th }}$ graders did not. And, so on.

To take advantage of this, I specify a second model that allows for unique grade effects within states, as well as state-year specific intercepts:

$$
D_{s g t}=\beta_{1} \vec{X}_{s t}+\beta_{2} \vec{E}_{s g t}+\mu_{s g}+\phi_{s t}+\varepsilon_{s g t}
$$

This strategy identifies effects of exit exams by comparing dropout rates for students in grades affected by the exams within a state, separate from the usual patterns of dropout observed for a particular grade in each state. Because Model 2 limits threats to identification that could arise if grade-specific dropout rates were changing within states in a way that was coincident with the implementation of exit exams, it is the preferred model here.

Below, I estimate both models first where the outcome is the dropout rate for all students in a grade, state and year. I then distinguish between dropout rates by gender and race. Because the distribution of dropout rates is bounded at zero and positively skewed, all models are in log-linear form. The log-linear specification also makes comparison of relevant effects for different groups somewhat easier. In any case, the findings below are not sensitive to the use of logs.

Finally, because states differ in the level of alignment of their exit exams, and some states change the grade alignment of their exams, I distinguish between the effects of exit exams aligned at the high school level and those aligned at less than the high school level by including separate indicators for both types of exit exams. All models are 
estimated using weighted least squares, with enrollment in state/grade/year as weights.

Standard errors are clustered at the state-grade level.

\section{Results}

In Table 1, I present descriptive statistics for the analytical sample. There are a total of 2,850 state-year-grade observations in the panel. ${ }^{3}$ Students in about a third (0.327) of those grades were required to pass some form of exit exam for graduation. About one-tenth (0.104) were required to pass the more challenging exit exams aligned at the high school level. During the period, annual dropout rates were between 3.98 and 5.77 percent, rising with grade.

As a first step to understanding overall patterns in high school dropout and exit exams, consider the time series in Figures 1 and 2. Figure 1 makes clear that dropout rates were falling for all student groups between the early 1990 s and $2008 .^{4}$ On average, dropout rates fell from just under 6 percent of students to less than 4 percent by 2008 . The decline was not even, remaining close to 6 percent until 1997, and then falling thereafter. Similar inter-temporal patterns are apparent for students defined by race and gender, even if these groups differed in levels. ${ }^{5}$ Black males had the highest rate of dropout, peaking at over 11 percent in 1996, and then falling to 6 percent by 2008. At the same time, the dropout rate among white females fell from about 3 percent to under 2 percent.

Figure 2 illustrates that over this period, the number of states with exit exams increased. This increase appears relatively steady, beginning in the late 1990s. The real

\footnotetext{
${ }^{3}$ The panel consists of 16 years, 50 states, and 4 grades per state, but some states did not report graduation rates in all years.

${ }^{4}$ While Figure 2 shows dropout rates for $9^{\text {th }}$ grade students only, the same trends appear for all grades.

${ }^{5} \mathrm{I}$ focus on white and black students exclusively because the number of students in relevant grades in other racial/ethnic groups in some less populous states is very small.
} 
story in Figure 2, however, is that the percent of states adopting tough exit exams (aligned to high school levels), rises slowly during the early part of the panel, and then increases markedly during latter part of the period. So, in the aggregate, Figures 1 and 2 make clear that the last two decades were a period of expanding exit exams and falling dropout rates.

In Table 2, I present estimates of the models of exposure to exit exams on dropout rates. In columns (1) and (2) I present results from Model 1, above. In columns (3) and (4) I add in state-grade as well as state-year fixed effects, the specification from Model 2, above. In the odd numbered columns, I estimate models where the impact of exposure to exit exams on dropout is constrained to be equal across grades. In the even numbered columns, I allow the effect to vary by grade. The results of Model 1 are not consistent with any change in dropout risk subsequent to the adoption of exit exams. Regardless of whether students faced exit exams aligned at the high school level or at levels lower than high school, there is no evidence in Model 1 of effects on dropout rates overall, or for any grade. In Model 2, however, the estimates of the effects of exit exams on dropout rates overall are positive, and significant at the conventional level for exit exams aligned at the high school level, and at the 10 percent level for exams aligned at grades below high school.

The differences between the results from Models 1 and 2 are interesting and suggest that the timing of states' decisions to adopt or strengthen exit exams is not independent of trends in dropout rates. Recall that Model 1 identifies the impact of exit exams by comparing changes in drop out rates in states changing their testing policies to changes in other states not making similar changes, while Model 2 identifies effects by 
comparing changes in dropout rates for students in a particular grade net of within-state grade specific trends. That we find no effect of exit exams in Model 1, but positive and significant effects in Model 2 is consistent with a process of implementation of exit exams in state/grades where dropout rates are trending down, but a slight increase in dropout in those state/grades subsequent to the new testing regime. This might occur if states adopting these exams are also implementing other reforms that have positive impacts on outcomes, or are the states that feel least threatened by new requirements. Because Model 1 does not differentiate between the within grade general trends and policy effects, it confounds the effects of any policy that increased dropout during a period with any persistent general decline in dropout rates.

A second important lesson from the results presented in Table 2 is that regardless of the level at which an exit exam is aligned, the effect on dropout is driven entirely by increases in dropout among $12^{\text {th }}$ grade students. The results in column 4 of Table 2 , suggest that dropout rates of $12^{\text {th }}$ graders are more than a third higher than typical for $12^{\text {th }}$ graders in the same state in years where students were not required to pass exit exams. ${ }^{6}$

In Table 3, I re-estimate Model 2 separately for black and white students and for each of these groups for boys and girls separately. In the first four columns, I present results for black students. The second sets of columns present results for white students. The results in Table 3 suggest that exit exams have relatively large effects on the dropout behavior of white students. Regardless of whether or not they are aligned at the high school level, exit exams are associated with an increase in dropout rates among white boys and girls in later grades, especially $12^{\text {th }}$ grade. The coefficient estimates suggest

\footnotetext{
${ }^{6}$ Taking exponents of the coefficients $(0.31$ and 0.41$)$, dropout rates are $36.3 \%$ or $50.7 \%$ higher for $12^{\text {th }}$ grade students faced with exit exams, depending on the level of alignment of the exam.
} 
that regardless of the level of alignment, exit exams increase 12 grade dropout rates for these groups by about 50 percent. For black students, high school aligned exit exams are associated with higher dropout rates in $12^{\text {th }}$ grade, significant for girls only, but the patterns at lower grades are much less clear.

The effect for $12^{\text {th }}$ grade students is interesting, and the same as the pattern found by Dee and Jacob (2007) in Minnesota. There are several potential explanations for this pattern. The first is due to the way exams were implemented: Students typically take exit exams early in their high school careers, and repeat them if an only if they fail. While failing an exam in $9^{\text {th }}$ or $10^{\text {th }}$ grade surely causes problems for students, the costs to poor performing students increase with grade as the consequences of failure rise while the opportunity for retesting diminishes. An alternative explanation consistent with this pattern is that any alignment of incentives, focus on academic success, or targeting of instruction and remediation occur only in lower grades, while the anticipated behavioral responses on the part of students, teachers or schools may be abandoned after repeated signs of failure. A final explanation is that the observed dropout of $12^{\text {th }}$ graders is precisely the intended consequence of failure of high stakes exit exams: the completion of high school without earning diploma because of a students' inability to demonstrate sufficient knowledge of tested subject matter.

Unfortunately, the IPEDS data provides no ability to sort out the first two explanations. There is, however, a way to gain insight into the importance of the third explanation; that relatively high dropout rates in $12^{\text {th }}$ grade are the intended consequence or at least a natural outcome of a meaningful exam, since all $12^{\text {th }}$ graders who leave high school without a diploma are counted among the dropouts. While all states with exit 
exams make passing the exams mandatory for graduation in due course, they differ in whether there are "alternative pathways" to a high school credential for students who fail the exams. These alternative pathways are quite varied: Some states permit students who cannot pass exit exams to take alternative exams; others permit substitution of satisfactory performance in selected courses or an end-of-course project (portfolio assessment) in place of the exit exam. Or, states may permit students who have failed to pass exit exams to receive a credential other than a diploma, such as a certificate of achievement or completion (CEP, 2008). Of the 25 states with exit exams in 2008, 19 allowed some form of alternative pathway.

In states with alternative pathways, even students who fail can complete high school with a diploma or some other certification of completion. Dropouts in these states are students who have left school after $12^{\text {th }}$ grade having neither passed the exit exam, nor satisfied the alternative requirements for high school completion. Because passing an exit exam is not strictly required for graduation in these states, comparing changes in dropout rates in states with alternative pathways to changes in states without one can provide insight into how much of the impact of exit exams is due to the additional requirements placed on students prior to completing high school and how much is due to forced exit. If the effect of exit exams was due to failing students finishing the school year but not being awarded a diploma, we would expect exit exams to little effect in states where alternative pathways are available.

To examine whether the effects of exit exams vary in this way, I estimate models that distinguish between states with exit exams that provide alternative pathways to failing students, and states where passing exit exams is absolutely mandatory for students 
to graduate high school. I present results from this estimation, in Table 4. For parsimony, I do not distinguish between the level of alignment, and I present results only from the model which includes state-specific grade and time effects. Further, I distinguish between effects in $12^{\text {th }}$ grade and all other grades, only. The first three rows of Table 4 are estimates of the impact of exit exams in states that provide some form of alternative pathway to a high school credential. Below these are estimates of dropout effects of exit exams in states where no alternative pathway is available. I then present pvalues from hypotheses tests that the impacts on dropout rates in $12^{\text {th }}$ grade are the same in states with/without alternative pathways. Again, I present these results separately by race/gender group.

For all groups, high school exit exams increase high school dropout, regardless of whether students are offered alternative pathways to graduation. For all groups, the impact of exams in states that offer alternative pathways is large and precisely estimated. In each case, the effect of exams in states with no alternative pathway is larger, but the estimates are less precise. Consequently, in three of four cases, the impacts of exit exams in states with no alternative pathways is not significantly different than the impact in states were alternative pathways permit failing students to receive a diploma or certificate with additional work. That exit exams have substantial effects on dropout, even when passing the exam is not mandatory, suggests that part of the mechanism operating here is the impact of additional hurdles to graduation increasing dropout among marginal students. At the same time, there is suggestive evidence that effects are even larger if no alternative pathway is available, where failing students who have run out of options and time simply leave high school after twelve years with no diploma or certificate. 


\section{Conclusions}

In this paper I have attempted to expand what is known about the impact of a new round of student level accountability on high school dropout, an outcome known to be associated with a wide variety of economic and social costs. I find evidence that high school dropout rates rise with the implementation of exit exams, but modest overall. I find that dropout rates increase mainly for students in the $12^{\text {th }}$ grade, the grade at which re-taking exams is no longer an option. I find some evidence of differences for different groups, and clear evidence that effects are large regardless of whether or not states provide alternative pathways to receive a diploma or alternative credential for students that cannot pass exit exams.

Overall, these results suggest that the recent expansion of exit exams has not resulted in an unambiguous increase in high school dropout rates. Exit exams have led to higher dropout rates, in the aggregate, but that increase is concentrated on students in $12^{\text {th }}$ grade, where additional attempts to pass exams are not possible. That impacts on dropout are not apparent until late in high school can provide some comfort to educators and policy makers concerned about that exit exams might limit educational attainment: Because exit exams affect dropout only at the end of high school, effects on attainment are at the margin and smaller than the decline in attainment we would expect if exit exams induced dropout early in high school.

At the same time, the results here suggest that a widely used policy to limit the impacts of exit exams on high school completion has little effect on dropout: In states where students can otherwise earn high school diplomas or other credentials even when 
unable to pass exit exams, dropout increases in $12^{\text {th }}$ grade at about the same rate as in other states without such alternative pathways. Whether this should be of any concern to policy makers depends on the economic or social costs of the marginal increase in $12^{\text {th }}$ grade dropout rates in states with exit exams. Relevant to this assessment are the potential losses for students induced to leave high school a bit earlier than they might otherwise. There is good evidence that the value of an earned degree is large (Tyler et al, 2000), but it is not clear that estimates of these sheepskin effects apply to students at this margin. Other relevant considerations are the achievement gains which exit exams might engender. Identifying these are clearly important topics for future research. 


\section{References}

Airasian, Peter W. 1987. "State Mandated Testing and Educational Reform," American Journal of Education, v. 95(3), pp 393-412.

Amrein, Audrey L., and David C. Berliner. 2002. "High Stakes Testing, Uncertainty and Student Learning," Educational Policy Analysis Archives, v10(18).

Bishop, John H. 2001. "A Steeper, Better Road to Graduation." Education Next v1(4): 56-61.

Center on Education Policy. 2008. State High School Exams: A Move Toward End of Course Exams. (Washington, DC: Center on Education Policy).

Dee, Thomas S., 2003. "The 'First Wave' of Accountability." In Paul Peterson and Martin West (editors) No Child Left Behind? The Politics and Practice of Accountability. (Washington: Brookings). Pp. 1-20.

Dee, Thomas, and Brian Jacob. 2007. "Do High School Exit Exams Influence Educational Attainment or Labor Market Performance?” in Adam Gamoran (editor), Standards-Based Reform and the Poverty Gap. Washington: Brookings) pp. 154-97.

Fredericksen, N. 1994. The Influence of Minimum Competency Tests on Teaching and Learning. (Princeton, NJ: Educational Testing Service).

Goldman, Jeri J. 1984. "Political and Legal Issues in Minimum Competency Testing," Educational Forum. 48(2), pp 207-16.

Griffin, B.W., and M.H. Heidorn. 1996. “An Examination of the Relationship Between Minimum Competency Test Performance and Dropping Out of High School," Educational Evaluation and Policy Analysis. 18(3): 243-52.

Jacob, Brian. 2001. "Getting Tough: The impact of high school graduation exams." Educational Evaluation and Policy Analysis. 23(1): 99-121.

Martorell, Paco. 2005. "Do High School Exit Exams Matter? Evaluating the Effects of High School Exit Exams on Student Outcomes.” Working Paper. University of California, Berkeley.

McDill, Edward L. 1985. "Raising Standards and Retaining Students: The Impact of the Reform Recommendations on Potential Dropouts," Review of Educational Research, 55(4), pp 415-33.

National Center for Education Statistics. 2010. NCES Common Core of Data State Dropout and Completion Data File: School Year 2007-08. 
Ou, D. 2009. To leave or not to leave? A regression discontinuity analysis of the impact of failing the high school exit exam. London: Centre for Economic Performance, London School of Economics.

Papay, John P., Murnane, Richard J., \& Willett, John B. 2010. The consequences of high school exit examina-tions for low-performing urban students: Evidence from Massachusetts. Educational Evaluation and Policy Analysis, 32, 5-23.

Peterson, Paul E., and Martin R. West. 2003. No Child Left Behind? The Politics and Practice of School Accountability. (Washington: Brookings Institution).

Pipho, Chris. 1978. "Minimum Competency Testing in 1978: A Look at State Standards," Phi Delta Kappan, v.59(9), pp. 585-88.

Purkey, S.C., and M.S. Smith. 1985. "Effective Schools: A review," The Elementary School Journal, 83(4), pp. 427-52.

Reardon, Sean F, Nicole Arshan, Allison Atteberry, and Michal Kurlaender. 2009. Effects of Failing a High School Exit Exam on Course Taking, Achievement, Persistence, and Graduation." Educational Evaluation and Policy Analysis. v.32(4), pp. 498-520.

Roderick, Melissa, and Mimi Engel. 2001. "The Grasshopper and the Ant: Motivational responses of low-achieving students to high-stakes testing." Educational Evaluation and Policy Analysis. v.23(3), pp. 197-227.

Stillwell, Robert. 2010. NCES Common Core of Data State Dropout and Completion Data File: School Year 2007-08 (NCES 2010-365). National Center for Education Statistics. Institute of Education Sciences, U.S. Department of Education. Washington, DC.

Tyler, John H., Richard J. Murnane; John B. Willett, 2000. "Estimating the Labor Market Signaling Value of the GED," The Quarterly Journal of Economics, 115(2), pp. 431-68.

Walstad, William B. 1984. “Analyzing Minimal Competency Test Performance," Journal of Educational Research, 77(5), pp. 261-66.

Warren, John R. 2005. "State-Level High School Completion Rates: Concepts, Measures and Trends. Education Policy Analysis Archives. http://eepa.asu.edu/epaa/v13n51

Warren, John R., Krista N. Jenkins, and Rachael Kulick. 2006. "High School Exit Examinations and State-Level Completion and GED Rates, 1973-2000." Educational Evaluation and Policy Analysis 28: 131-152. 
Winfield, L.F. 1990. School Competency Testing Reforms and Student Achievement: Exploring a National Perspective," Educational Evaluation and Policy Analysis, 12(2), pp. 157-73.

Zabala, D., A. Minnici, et al. 2007. "It's Different Now:" How Exit Exams Are Affecting Teaching and Learning in Jackson and Austin, Center on Education Policy. 1001 Connecticut Avenue NW Suite 522, Washington, DC 20036. 
Figure 1

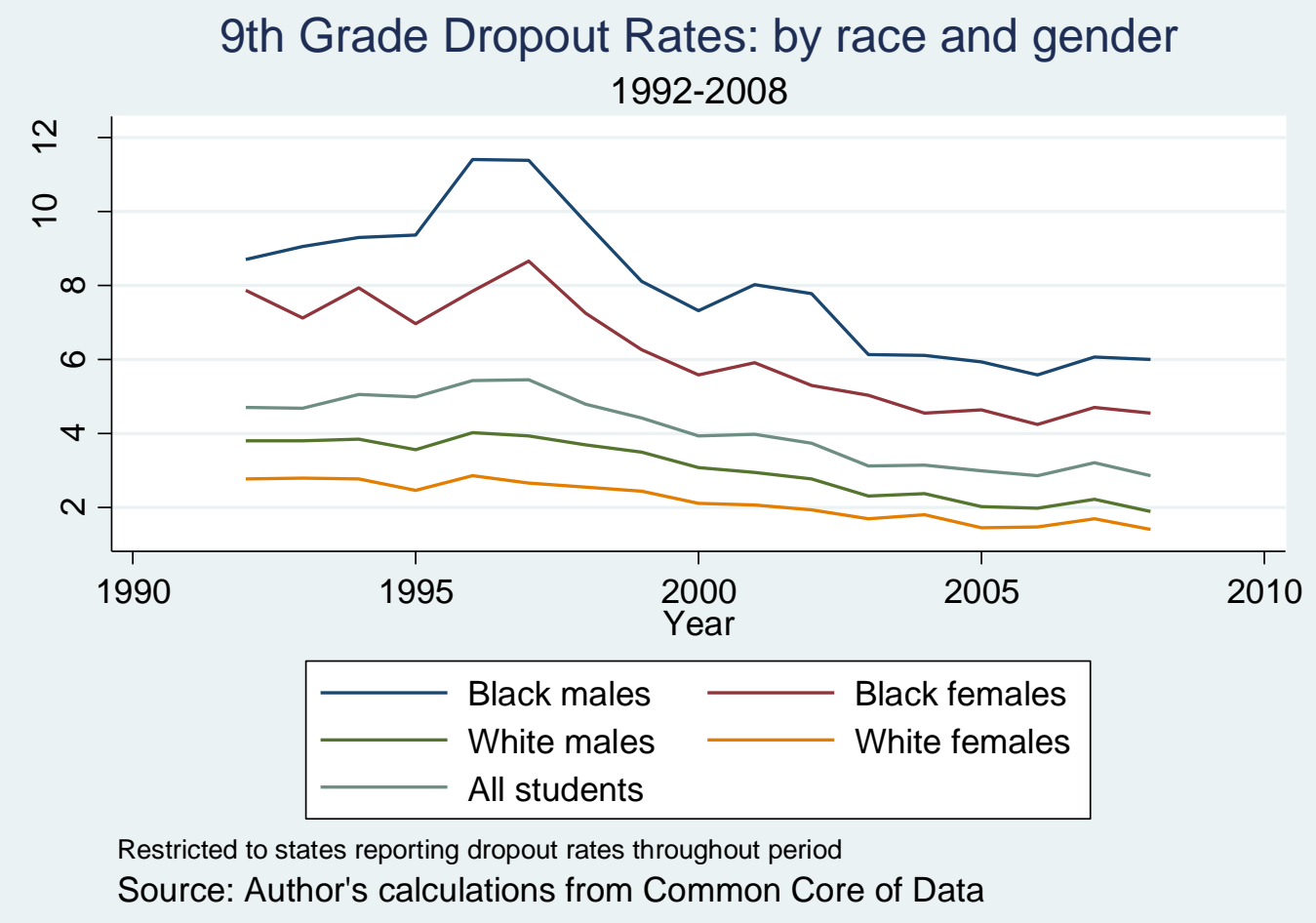


Figure 2

Number of States with Exit Exams: by allignment level 1992-2008

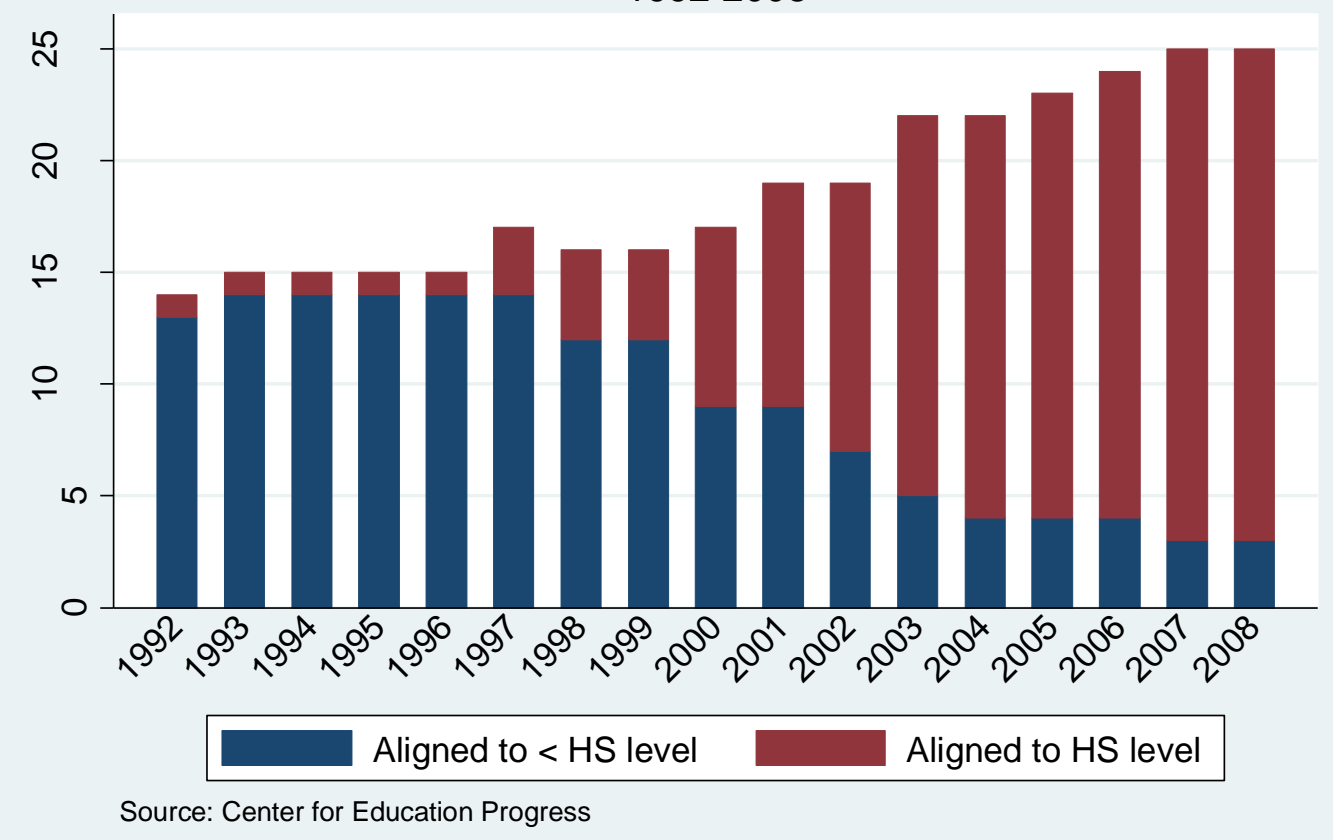


Table 1 Descriptive Statistics

\begin{tabular}{lcc} 
Variable & Mean & $\begin{array}{c}\text { Standard } \\
\text { Deviation }\end{array}$ \\
\hline Employment (100,000s) & 31.59 & 33.89 \\
Per Capita Income & $27,846.67$ & 7140.11 \\
Population (millions) & 9.07 & 1.47 \\
Exit Exam (0/1) & 0.335 & 0.472 \\
HS Aligned Exit Exam (0/1) & 0.135 & 0.342 \\
9th grade - dropout rate & 3.88 & 2.19 \\
10th grade - dropout rate & 4.69 & 2.20 \\
11th grade - dropout rate & 5.11 & 2.02 \\
12th grade - dropout rate & 5.71 & 3.16 \\
Overall dropout rate & 4.85 & 2.52 \\
Black female dropout rate & 7.55 & 12.13 \\
Black male dropout rate & 10.09 & 14.46 \\
White female dropout rate & 3.11 & 1.76 \\
White male dropout rate & 4.17 & 2.32
\end{tabular}

$\mathrm{n}=2,850$ 
Table 2 Exit Exams and High School Dropout

\begin{tabular}{|c|c|c|c|c|}
\hline \multirow[b]{2}{*}{ Independent variable } & \multicolumn{2}{|c|}{ Model 1} & \multicolumn{2}{|c|}{ Model 2} \\
\hline & $(1)$ & (2) & (3) & (4) \\
\hline Exam & $\begin{array}{l}-0.03 \\
(0.07)\end{array}$ & & $\begin{array}{l}0.10^{*} \\
(0.06)\end{array}$ & \\
\hline Exam $*$ grade 9 & & $\begin{array}{c}0.09 \\
(0.12)\end{array}$ & & $\begin{array}{l}-0.04 \\
(0.10)\end{array}$ \\
\hline Exam $*$ grade 10 & & $\begin{array}{l}-0.14 \\
(0.11)\end{array}$ & & $\begin{array}{c}0.00 \\
(0.11)\end{array}$ \\
\hline Exam $*$ grade 11 & & $\begin{array}{c}-0.19 * \\
(0.11)\end{array}$ & & $\begin{array}{c}0.12 \\
(0.12)\end{array}$ \\
\hline Exam $*$ grade 12 & & $\begin{array}{l}-0.12 \\
(0.16)\end{array}$ & & $\begin{array}{c}0.31 * * \\
(0.13)\end{array}$ \\
\hline Exam (HS aligned) & $\begin{array}{l}-0.04 \\
(0.07)\end{array}$ & & $\begin{array}{c}0.12 * * \\
(0.05)\end{array}$ & \\
\hline Exam (HS aligned)* grade 9 & & $\begin{array}{l}-0.03 \\
(0.12)\end{array}$ & & $\begin{array}{l}-0.03 \\
(0.13)\end{array}$ \\
\hline Exam (HS aligned)* grade 10 & & $\begin{array}{l}-0.04 \\
(0.10)\end{array}$ & & $\begin{array}{l}-0.02 \\
(0.09)\end{array}$ \\
\hline Exam (HS aligned)* grade 11 & & $\begin{array}{l}-0.07 \\
(0.09)\end{array}$ & & $\begin{array}{c}0.11 \\
(0.14)\end{array}$ \\
\hline Exam (HS aligned)* grade 12 & & $\begin{array}{c}0.17 \\
(0.17)\end{array}$ & & $\begin{array}{c}0.41 * * \\
(0.14)\end{array}$ \\
\hline R-squared & 0.553 & 0.562 & 0.875 & 0.879 \\
\hline State, year and grade effects? & Yes & Yes & No & No \\
\hline State-year effects? & No & No & Yes & Yes \\
\hline State-grade effects? & No & No & Yes & Yes \\
\hline
\end{tabular}

Robust standard errors in parentheses

$* * \mathrm{p}<0.05, * \mathrm{p}<0.1$

All models control for employment, income, population, and fixed effects as described in text. 
Table 3 Exit Exams and High School Dropout: By Race and Gender

\begin{tabular}{|c|c|c|c|c|c|}
\hline \multirow{2}{*}{$\begin{array}{l}\text { Independent variable } \\
\text { Exam }\end{array}$} & Black Males & Black Females & White Males & \multicolumn{2}{|c|}{ White Females } \\
\hline & $\begin{array}{c}-0.31 * \\
(0.19)\end{array}$ & $\begin{array}{c}0.14 \\
(0.09)\end{array}$ & $\begin{array}{c}0.07 \\
(0.05)\end{array}$ & $\begin{array}{l}0.11^{*} \\
(0.06)\end{array}$ & \\
\hline Exam $*$ grade 9 & $\begin{array}{l}-0.16 \\
(0.22)\end{array}$ & $\begin{array}{l}0.262 \\
(0.17)\end{array}$ & $\begin{array}{l}-0.17 \\
(0.13)\end{array}$ & & $\begin{array}{c}-0.15 \\
(0.14)\end{array}$ \\
\hline Exam $*$ grade 10 & $\begin{array}{c}-0.17 * \\
(0.10)\end{array}$ & $\begin{array}{r}-0.301 \\
(0.23)\end{array}$ & $\begin{array}{c}0.13 \\
(0.15)\end{array}$ & & $\begin{array}{c}0.15 \\
(0.17)\end{array}$ \\
\hline Exam $*$ grade 11 & $\begin{array}{l}-0.18 \\
(0.11)\end{array}$ & $\begin{array}{r}-0.271 \\
(0.19)\end{array}$ & $\begin{array}{c}0.22 \\
(0.16)\end{array}$ & & $\begin{array}{c}0.23 \\
(0.18)\end{array}$ \\
\hline Exam * grade 12 & $\begin{array}{l}-0.19 \\
(0.17)\end{array}$ & $\begin{array}{l}-0.013 \\
(0.20)\end{array}$ & $\begin{array}{c}0.45^{* *} \\
(0.17)\end{array}$ & & $\begin{array}{c}0.48^{* *} \\
(0.20)\end{array}$ \\
\hline Exam (HS aligned) & $\begin{array}{l}-0.31 * \\
(0.17)\end{array}$ & $\begin{array}{c}0.15^{*} \\
(0.087)\end{array}$ & $\begin{array}{c}0.01 \\
(0.04)\end{array}$ & $\begin{array}{c}0.05 \\
(0.04)\end{array}$ & \\
\hline Exam (HS aligned)* grade 9 & $\begin{array}{l}-0.37 * \\
(0.21)\end{array}$ & $\begin{array}{l}0.232 \\
(0.17)\end{array}$ & $\begin{array}{c}-0.26^{* *} \\
(0.13)\end{array}$ & & $\begin{array}{l}-0.21 \\
(0.14)\end{array}$ \\
\hline Exam (HS aligned)* grade 10 & $\begin{array}{c}0.03 \\
(0.14)\end{array}$ & $\begin{array}{r}-0.273 \\
(0.21)\end{array}$ & $\begin{array}{c}0.08 \\
(0.14)\end{array}$ & & $\begin{array}{c}0.10 \\
(0.15)\end{array}$ \\
\hline Exam (HS aligned)* grade 11 & $\begin{array}{c}0.01 \\
(0.14)\end{array}$ & $\begin{array}{l}-0.265 \\
(0.17)\end{array}$ & $\begin{array}{l}0.27 * \\
(0.15)\end{array}$ & & $\begin{array}{c}0.24 \\
(0.16)\end{array}$ \\
\hline Exam (HS aligned)* grade 12 & $\begin{array}{c}0.24 \\
(0.19)\end{array}$ & $\begin{array}{l}0.282 \\
(0.18)\end{array}$ & $\begin{array}{l}0.58 * * \\
(0.16)\end{array}$ & & $\begin{array}{c}0.56^{* *} \\
(0.18)\end{array}$ \\
\hline R-squared & 0.753 & 0.920 & 0.960 & 0.958 & 0.962 \\
\hline State-year effects & Yes & Yes & Yes & Yes & Yes \\
\hline State-grade effects & Yes & Yes & Yes & Yes & Yes \\
\hline
\end{tabular}

Robust standard errors in parentheses

** $\mathrm{p}<0.05$ All models control for employment, income, population, and fixed effects as described in text. 
Table 4 Exit Exams, Alternative Pathways and High School Dropout

\begin{tabular}{|c|c|c|c|c|c|c|c|c|}
\hline \multirow{2}{*}{$\begin{array}{l}\text { Independent variable } \\
\text { Exam with Alt. Pathway }\end{array}$} & \multicolumn{2}{|c|}{ Black Males } & \multicolumn{2}{|c|}{ Black Females } & \multicolumn{2}{|c|}{ White Males } & \multicolumn{2}{|c|}{ White Females } \\
\hline & $\begin{array}{c}0.026 \\
(0.099)\end{array}$ & & $\begin{array}{c}0.088 \\
(0.078)\end{array}$ & & $\begin{array}{l}-0.046 \\
(0.071)\end{array}$ & & $\begin{array}{l}-0.011 \\
(0.068)\end{array}$ & \\
\hline Exam $(w / \text { Alt })^{*}$ grade $<12$ & & $\begin{array}{l}-0.038 \\
(0.137)\end{array}$ & & $\begin{array}{c}0.058 \\
(0.120)\end{array}$ & & $\begin{array}{c}-0.168 * \\
(0.095)\end{array}$ & & $\begin{array}{l}-0.112 \\
(0.094)\end{array}$ \\
\hline Exam (w/ Alt)* grade 12 & & $\begin{array}{l}0.398 * * \\
(0.081)\end{array}$ & & $\begin{array}{c}0.274 * * \\
(0.089)\end{array}$ & & $\begin{array}{l}0.377 * * \\
(0.057)\end{array}$ & & $\begin{array}{l}0.351 * * \\
(0.047)\end{array}$ \\
\hline Exam w/out Alt. Pathway & $\begin{array}{c}0.133 \\
(0.103)\end{array}$ & & $\begin{array}{c}0.171 \\
(0.113)\end{array}$ & & $\begin{array}{l}0.112 * \\
(0.058)\end{array}$ & & $\begin{array}{l}0.154 * * \\
(0.055)\end{array}$ & \\
\hline Exam (No Alt.) ${ }^{*}$ grade $<12$ & & $\begin{array}{l}-0.139 \\
(0.107)\end{array}$ & & $\begin{array}{l}-0.146 \\
(0.095)\end{array}$ & & $\begin{array}{l}-0.077 \\
(0.069)\end{array}$ & & $\begin{array}{l}-0.026 \\
(0.074)\end{array}$ \\
\hline Exam $($ No Alt.)* grade 12 & & $\begin{array}{l}0.584^{*} \\
(0.352)\end{array}$ & & $\begin{array}{l}0.700^{*} \\
(0.376)\end{array}$ & & $\begin{array}{l}0.538 * * \\
(0.119)\end{array}$ & & $\begin{array}{l}0.614 * * \\
(0.125)\end{array}$ \\
\hline $\begin{array}{l}H_{o}: \operatorname{Exam}(w / \text { Alt }) * \text { grade } 12 \\
=\operatorname{Exam}(\text { No Alt. }) * \text { grade } 12\end{array}$ & & $p=0.608$ & & $p=0.271$ & & $p=0.226$ & & $p=0.050$ \\
\hline R-squared & 0.878 & 0.899 & 0.883 & 0.904 & 0.957 & 0.972 & 0.959 & 0.973 \\
\hline State-year effects? & Yes & Yes & Yes & Yes & Yes & Yes & Yes & Yes \\
\hline State-grade effects? & Yes & Yes & Yes & Yes & Yes & Yes & Yes & Yes \\
\hline
\end{tabular}

Robust standard errors in parentheses

$* \mathrm{p}<0.10 ; * * \mathrm{p}<0.05$ All models control for employment, income, population, and fixed effects as described in text. 